\title{
Bürokratik Okul Yapısı ile Müdür Yönetim Tarzları Arasındaki İlişkilerin İncelenmesi
}

\section{Investigation of the Relationship between Bureaucratic School Structure and Principal Management Styles}

\author{
Müslim ALANOĞLU1 ${ }^{1}$ Zülfü DEMIRTAȘ²
}

• Geliş Tarihi: 04.05.2019 • Kabul Tarihi: 06.07.2019• Çevirimiçi Yayın Tarihi: 07.07.2019

$\ddot{\mathbf{O z}}$

$\mathrm{Bu}$ araştırmanın amacı öğretmen algılarına göre okulun bürokratik yapısı ile okul müdürü yönetim tarzı arasındaki ilişkiyi incelemektir. Bu amaca ulaşmak için ilişkisel tarama modeli kullanılmıştır. Araştırmanın çalışma grubunu 2017-2018 eğitim-öğretim yılında Mersin il merkezinde bulunan liselerde görev yapan 286 öğretmen oluşturmaktadır. Araştırma verileri Okul Yapısının Etkililiği ve Algılanan-Müdür Yönetim Tarzı ölçekleri yardımıyla toplanmıştır. Araştırmada okulların sahip olduğu bürokratik yapı çoğu zaman kolaylaştırıcı, bazen ise engelleyici bulunmuştur. Okul müdürleri çoğu zaman işbirlikli, bazen otoriter, nadiren de ilgisiz ve karşı koyucu yönetim tarzı sergilemektedir. Kolaylaştırıcı yapı ile işbirlikli yönetim tarzı arasında yüksek düzeyde ve pozitif; otoriter, ilgisiz ve karşı koyucu yönetim tarzı arasında ise orta düzeyde ve negatif ilişki bulunmuştur. Engelleyici yapı ile işbirlikli yönetim tarzı arasında orta düzeyde ve negatif; otoriter, ilgisiz ve karşı koyucu yönetim tarzı arasında ise orta düzeyde ve pozitif anlamlı ilişki bulunmaktadır. Kolaylaştırıcı yapı işbirlikli yönetim tarzını yüksek düzeyde olumlu, engelleyici yapı ise düşük düzeyde ve olumsuz yordamaktadır. Kolaylaştırıcı yapı otoriter, ilgisiz ve karşı koyucu yönetim tarzını yordamazken, engelleyici yapı her üç yönetim tarzını pozitif yordamaktadır.

Anahtar sözcükler: bürokratik yapı, yönetim tarzı, okul, müdür

Attf:

Alanoğlu, M. ve Demirtaş, Z.(2020). Bürokratik okul yapısı ile müdür yönetim tarzları arasındaki ilișkilerin incelenmesi. Pamukkale Üniversitesi Eğitim Fakültesi Dergisi, 48, 199-213. doi: 10.9779/pauefd.560610

\footnotetext{
${ }^{1}$ Dr., muslimalanoglu@gmail.com ORCID: 0000-0003-1828-4593

2 Prof. Dr., Frrat Üniversitesi, Eğitim Bilimleri Bölümü, Eğitim Yönetimi Anabilim Dalı, ORCID: 0000-0002-10725772,zdemirtas@firat.edu.tr
} 


\begin{abstract}
The purpose of this study was to investigate the relationship between school bureaucratic structure and principal management style according to teachers' perceptions. Relational-survey model was used to achieve this purpose. The sample of the study consisted of 286 teachers working in high schools in the city center of Mersin in 2017-2018 academic year. The research data were collected with the help of the Enabling School Structure and Perceived School Principal Management Styles scales. In the study, the bureaucratic structure of the schools was found to be usually enabling and sometimes obstructive. Principals often exhibit cooperative, sometimes authoritative, rarely indifferent and resistant management styles. Between enabling structure and cooperative management style was found high and positive; between enabling structure and authoritative, indifferent and resistant management style there was moderate and negative relationship. There was moderate and negative relationship between obstructive structure and cooperative management style; there was moderate and positive relationship between authoritative, indifferent and resistant management style. The enabling structure predicted the cooperative management style highly positive and the obstructive structure predicted low and negative. While the enabling structure did not predict the authoritative, indifferent and resistant management style, the obstructive structure positively predicted all three management styles.

Keywords: bureaucratic structure, management style, school, principal
\end{abstract}

\title{
Cited:
}

Alanoğlu, M. \& Demirtaş, Z.(2020). Investigation of the relationship between bureaucratic school structure and principal management styles. Pamukkale Üniversitesi Eğitim Fakültesi Dergisi, 48, 199-213. doi: 10.9779/pauefd.560610 


\section{Giriş}

Eğitim sisteminin alt sistemi ve aynı zamanda temel sistemi olan okulların etkili işlemesi kurumsal bir yapıya sahip olmaları ile mümkün olabilmektedir. Okulların sahip olduğu kurumsal yapıların çağın gereklerine uygun olması, yerine getirmeleri gereken rollerini başarılı bir şekilde gerçekleştirmelerine olanak sağlar. Hiç şüphesiz ki okulların başarısı öğretmenlerin okula ilişkin algı ve tutumları ile yakından ilişkilidir. Okullarda öğretmenlerin algı ve tutumlarının etkilendiği pek çok örgütsel ve bireysel faktörden birisinin de okulun sahip olduğu bürokratik yapı olduğu söylenebilir. Bürokratik yapı okuldaki bütün iş ve eylemlerin nasıl yapıldığı ile ilgilidir. Öğretmenlerin bu yapıya ilişkin algılarının görev yaptıkları okul müdürlerinin sergilediği yönetim tarzına ilişkin algıları ile ilişkili olduğu ve bu ilişkinin belirlenmesinin önemli olduğu düşünülmektedir.

\section{Bürokratik Yapı}

Bürokrasi; bureau (masa) ve cratie (egemenlik) kelimelerinden oluşan ve yetkilerin bürolar tarafindan kullanıldığı sistem anlamına gelmektedir (Buluç, 2009). Yani bürokrasi masaların ya da büroların egemenliği olarak ifade edilmektedir. Bu kavram ile aslında memurların toplum üzerinde artan egemenliğine vurgu yapılmaktadır (Çevikbaş, 2014). Türk Dil Kurumunda (2019) bürokrasi kavram1 "Devlet kurumlarında kırtasiye işlerini öne sürerek işlemleri zorlaştırma, kırtasiyecilik" olarak tanımlanmaktadır. Bu tanıma göre bürokratik yapı örgütü hantallaştırma özelliği taşımaktadır. Ancak bir yönetim yaklaşımı olarak bürokrasi, örgütlerin idari faaliyetleri ile ilgili alınan kararların uygulanmasına imkân veren bir yaklaşımdır ve insanların toplumsallaşmaya başladığı dönemden itibaren gelişen sosyal ilişkiler bürokratik örgütlenme ihtiyacını ortaya çıkarmıştır (Akçakaya, 2016). Bu anlamda bürokratik sistemlerin binlerce yıldır var olduğu söylenebilir. Kavramsal anlamda ise bürokrasinin, ilk olarak 1745 yılında Fransız Vincent de Gournay tarafindan kullanıldığg bilinmektedir (Yayla, 2001).

Bir örgütsel yaklaşım kavramı olarak bürokrasi, endüstri devrimi sonrası örgütsel yapıları işlevsel hale getirmek amacıyla geliştirilen yönetim yaklaşımlarından birini ifade etmek amacıyla Weber tarafından ortaya atılmıştır. Bürokrasilerin üst düzeyde idari verimlilik sağlayabileceklerini iddia eden Weber (Hoy ve Sweetland, 2001), örgütsel işlemlerin nesnel olması, hesaplanabilir bir işleyişin örgüte hâkim kılınması ve kişisel olmayan bir anlayışın ortaya konmasını bürokrasi olarak tanımlamaktadır (Aydoğan, 2013). Bu anlamda düşünüldüğünde bürokrasi esas itibari ile örgütlerde yönetimin görevlerini düzenlemek şeklinde tanımlanabilir (Bursalıoğlu, 2012). Genel olarak bütün örgütlerin Weber tarafından ortaya atılan bürokratik özelliklere sahip olduğunu belirten Hoy ve Miskel (2010), örgütlerde pek çok görevin tek bir kişi tarafından yerine getirilemeyeceğini bunun için iş bölümü ve uzmanlaşma gibi düzenlemeleri belirten kurallara ihtiyaç duyulduğunu ifade etmektedir. Söz konusu düzenlemeler yazılı kuralların örgütlerde hâkim duruma gelmesine neden olmuştur. Ancak yazılı kurallar çerçevesinde oluşturulan örgütsel şemalar örgütün işleyiş̧i konusunda her zaman doğru sonuçlar ortaya koymayabilir. Özellikle okul benzeri insan faktörünün önemli yer tuttuğu örgütlerde kişiler arası ilişkilerin göz önüne alınmaması örgütlerin sağlıklı işlemesinin önünde önemli bir engel olarak görülebilir (Bursalığlu, 2012). Ancak Hoy ve Sweetland (2001), bu durumdan hoşlanalım veya hoşlanmayalım okulların bürokratik yapılar olduğunu ifade etmektedir. Önemli olan okulların bürokratik olup olmaması değil sahip oldukları bürokrasinin nasıl işlediğidir. Adler ve Borys (1996), bürokrasinin engelleyici ve kolaylaştırıcı işlevlerinin 
olabileceğini ileri sürmüştür. Engelleyici işlev, örgütün tamamının bireysel özerkliğinin kaldırılması gerektiğini vurgular. Teşvik yerine örgütsel standartlardan sapmalar için ceza sistemi uygulanır (Hoy ve Sweetland (2001). Kolaylaştırıcı işlev ise, daha olumlu bir bakış ile bürokrasinin teknik işlevini vurgular. $\mathrm{Bu}$ işlev örgüt içi etkileşimi destekler, farklılıkları önemser, hataları öğrenme firsatı olarak görür ve aynı zamanda çalışanlara güven aşılar (Hoy ve Sweatland, 2001).

Öğretmenlerin algıladığı bürokratik okul yapısının onların okula yönelik algılarını etkilediği bilinmektedir. Öğretmenlerin gösterdiği örgütsel vatandaşlık davranışlarının okulun bürokratik yapısından etkilendiği (Karaman, Yücel ve Dönder, 2008) yapılan çalışma ile ortaya konmuştur. Okulun bürokratik yapısı ile örgütsel sessizlik ve sinizm (Demirtaş, Özdemir ve Küçük, 2016), öğretmen profesyonelizmi (Cerit, 2012), öğretmenlerin örgütsel sosyalleşmeleri (Erdoğan, 2012), öğretmenlerin farkındalık düzeyi ve güçlendirilmeleriyle (Watts, 2009) ve okula ilişkin öğretmen tutumlarıyla (Ömeroğlu, 2006) ilişkili olduğunu gösteren çalışmalar mevcuttur. Ayrıca bürokrasinin kolaylaştırıcı olması ile okul yöneticilerinin dönüşümcü liderlik davranışları arasında olumlu ilişki olduğu Buluç (2009) tarafından yapılan çalışmanın sonucu olarak raporlanmıştır. Bürokratik yapının etkilediği örgütsel ve bireysel faktörler göz önüne alındığında öğretmenler tarafından algılanan okul müdürü yönetim tarzının da bu yapıdan etkilenmesi beklenen değişkenlerden biri olarak karşımıza çıkmaktadır.

\section{Yönetim Tarzı}

Birden fazla insanın gerçekleştirmeye çalıştığı her faaliyetin yönetilmesi gerekliliği genel anlamda kabul gören bir husustur (Özgür, 2011). Bunun için bir yönetim sistemi ve bu sistemin başında faaliyetleri kontrol eden bir yöneticinin gerekliliği ortaya çıkmaktadır. Yılmaz’a (2016) göre yönetim çok uzun zamandan beri var olmasına karşın tek tanımı olmayan bir kavramdır. Genel anlamda yönetim örgütsel faaliyetlerin ahenkleştirilmesi olarak tanımlanabilir. Simkins (2005) yönetimi, bir eğitim kurumunun başarılı ya da başarısız olmasını belirleyen en önemli faktör olarak tanımlamaktadır. Yönetim kavramı, aynı zamanda, organize eden bir yöneticinin varlığını da zorunlu kılmaktadır. Robbins (2003) yöneticileri, başkalarıyla hedefe ulaşmaya çalışan, onların faaliyetlerini denetleyen ve örgütlerin hedeflerine ulaşmalarından sorumlu olan bireyler olarak tanımlamaktadır. Bununla beraber her yöneticinin belirlenen hedefleri gerçekleştirmek amacıyla kullandığı bir yönetim tarzının bulunduğu düşünülmektedir. Yönetim tarzı, bir yöneticinin örgütün yönetiminde kullandığı liderlik yöntemi (Ogunola, Kalejaiye ve Abrifor, 2013) ve yöneticiler tarafından kullanılan en iyi liderlik stratejisi olarak (Namıq, 2018) tanımlanabilir.

Alanyazın incelendiğinde yöneticilerin sergiledikleri yönetim tarzlarını sınıflandıran bilim adamlarının birbirinden farklı sınıflandırmalar yaptıkları görülmektedir. Etkin örgütleri diğer örgütlerden ayıran yapısal ve davranışsal özellikleri araştıran Likert (1961), yönetim tarzlarında otokratikten demokratiğe doğru dörtlü bir sınıflandırma öngörmüştür. Blake ve Mouton (1964) yaptıkları araştırmada işe yönelimli olandan insana yönelimli olana doğru birbirinden farklı yönetici sınıflandırmalarından bahsetmiştir. Başaran (2008) ise yönetim tarzlarını yetkeciden demokratiğe doğru dörtlü bir sınıflandırma ile ele almıştır. Yapılan farklı sınıflandırmalara rağmen genel anlamda yönetim tarzlarının otoriter ve işe ağılık veren yönetim tarzı ile demokratik ve işle birlikte insan ilişkilerine de önem veren yönetim tarzı arasında kategorilere ayrıldığ 1 görülmektedir. 
Okulların toplumsal anlamda önemi düşünüldüğünde yönetimlerinin oldukça önemli olduğunu söylemek yanlış olmayacaktır. Bununla birlikte yönetsel anlamda okulun vücut bulmuş halinin okul müdürünün sergilediği yönetim tarzı olduğu söylenebilir. Her ne kadar okullarda zümre başkanları ve müdür yardımcıları gibi orta kademe yöneticiler bulunsa da okulun yönetiminden temel anlamda sorumlu olan kişi okul müdürüdür. Okul müdürü kolaylaştırıcı, problem çözücü ve sosyal değişim ajanı olarak okulda temel karar vericidir (Kim ve Kim, 2005). Okul müdürünün sergilediği yönetim tarzı okula ait bileşenleri etkileyen önemli bir faktördür. $\mathrm{Bu}$ bileşenlerden öğretmenlerin okulun işleyişine doğrudan etkisi de düşünüldüğünde öğretmenlerin algıladıkları yönetim tarzlarının önemi daha iyi anlaşılacaktır.

Okulun sahip olduğu bürokratik yapının öğretmenlerin davranış, tutum ve algılarını etkilediği gibi okul yöneticisinin sergilediği yönetim tarzını da etkilemesi beklenir. Bürokratik yapının müdürün yönetim tarzını şekillendirmesinin yanı sıra öğretmenlerin bu tarza ilişkin algılarını da etkilemesi beklenen bir durumdur. Ancak örgütsel yapıyı belirleme konusunda önemli bir parametre olarak görülen bürokrasinin müdürlerin yönetim tarzları ile ilişkisinin bugüne kadar araştırılmamış olması alanyazın açısından bir eksiklik olarak kabul edilebilir. Okulda yapılması gereken iş ve işlemler kanun, yönetmelik, yönerge ve talimat emirler doğrultusunda yerine getirilmektedir. $\mathrm{Bu}$ düzenlemelere uyularak iş ve işlemlerin yapılma biçimi müdürün sergilediği yönetim tarzını şekillendirebilir. Bundan dolayı müdür yönetim tarzını ortaya çıkmasında bürokratik yapının işleyişi önemli bir rol oynayabilir. Ayrıca bu araştırma okul müdürlerinin sergiledikleri yönetim tarzlarının nedenlerinin anlaşılması bakımından okulun paydaşlarına önemli fikirler sunacaktır.

\section{Araştırmanın Amacı}

$\mathrm{Bu}$ araştırmanın temel amacı okulların sahip olduğu bürokratik yapının okul müdürlerinin sergiledikleri yönetim tarzları ile ilişkisini öğretmen algılarına göre belirlemektir. $\mathrm{Bu}$ amacı gerçekleştirmek amacıyla aşağıdaki sorulara cevap aranmıştır:

1. Öğretmen algılarına göre okulların engelleyici ve kolaylaştırıcı bürokratik yapısı ne düzeydedir?

2. Öğretmenlerin algıladıkları müdür yönetim tarzları ne düzeydedir?

3. Okulların bürokratik yapısı ile algılanan müdür yönetim tarzı arasındaki ilişki ne düzeydedir?

4. Okulların bürokratik yapısı algılanan müdür yönetim tarzını yordamakta mıdır?

\section{Yöntem}

Bu bölümde araştırmanın modeli, evren ve örneklemi, veri toplama araçları ile verilerin analizi sürecine ilişkin işlemler yer almaktadır.

\section{Araştırmanın Modeli}

Nicel araştırmalar kapsamında tasarlanan araştırmanın amacını gerçekleştirmek için öncelikle öğretmenlerin görev yaptıkları okulların bürokratik yapılarını ve okul müdürlerinin yönetim tarzlarını nasıl algıladıkları belirlenmiştir. Bu yönüyle araştırmanın tarama modelinde olduğu söylenebilir. Tarama modeli mevcut bir durumu olduğu şekliyle tanımlayan modeldir (Karasar, 
2010). Devamında değiş̧kenler arasındaki ilişkilerin yönünü ve boyutunu belirlemek amacıyla ilişkisel araştırma deseninden yararlanılmıştır. İlişkisel araştırma deseninde, açıklayıcı ve yordayıcı desen araştırmaları yapılabilmektedir. Açıklayıcı desende iki veya daha fazla değişken arasındaki ilişki ve bu ilişkinin düzeyi tespit edilirken, yordayıcı desen araştırmalarında hangi değişkenin diğerini yordadığı tespit edilir (Creswell, 2017). Mevcut araştırmada her iki araştırma deseninden de faydalanılmıştır.

\section{Evren ve Örneklem}

Araştırmanın evrenini 2017-2018 eğitim öğretim yılında Mersin il merkezinde bulunan resmi liselerde görev yapmakta olan öğretmenler oluşturmaktadır. Evrende yer alan okul ve öğretmen sayıları Mersin Il Milli Eğitim Müdürlüğ̈̈ Istatistik Bürosundan alınan veriler yardımıyla belirlenmiştir. 2017-2018 eğitim-öğretim yllında Mersin il merkezinde toplam 65 resmi lise ve 3194 öğretmen bulunmaktadır. Söz konusu evrenden basit seçkisiz örnekleme yöntemi ile toplam 286 öğretmene ulaşılmıştır. Örnekleme giren öğretmenlerin \%51’i $(n=146)$ kadın, \%49’u (n=140) erkektir; \%86.7'si ( $(n=248)$ lisans, \%13,3’ü $(n=38)$ lisansüstü mezunudur.

\section{Çalışmada Kullanılan Ölçme Araçları}

Araştırma kapsamında ihtiyaç duyulan verilerin toplanması amacıyla görüş bildiren öğretmenlerin demografik özelliklerinin bulunduğu Kişisel Bilgi Formu ile birlikte "Okul Yapısının Etkililiği” ve "Algılanan Müdür Yönetim Tarzı" ölçekleri kullanılmıştır. Söz konusu ölçekler ile ilgili bilgiler aşağıda sunulmuştur.

Okul yapısının etkililiği ölçeği; öğretmenlerin görev yaptıkları okulların bürokratik yapısını belirlemek amacıyla Hoy ve Sweetland (2000) tarafından geliştirilip Türkçeye uyarlaması Buluç (2009) tarafından yapılan, ölçek, okuldaki bürokratik yapının öğretmenlerin işlerini yaparken kolaylaştırıcı mı, engelleyici mi olduğunu belirlemeyi amaçlayan beşli Likert tipi on iki maddeden oluşmaktadır. Ölçeğin faktör yapısını incelemek için Özer (2010) tarafindan yapılan çalışmada, $\mathrm{KMO}$ değeri $=.87$, Bartlett küresellik testi $=5145.79, \mathrm{p}=.00$ bulunmuştur. Faktör analizi sonucunda, ölçeğin "Engelleyici bürokratik yapı" ve "Kolaylaştırıcı bürokratik yapı" şeklinde iki faktörden oluştuğu, Cronbah Alpha iç tutarlık katsayılarının da sırasıyla .83 ve .81 olduğu; bu iki faktörün toplam varyansın \% 53.76'sını açıkladığ1 görülmüştür. Mevcut çalışmada kolaylaştırıcı bürokratik yap1 için iç tutarlılık katsayısı .84, engelleyici bürokratik yapı için ise .88 olarak hesaplanmıştır.

Algılanan-müdür yönetim tarzı ölçeği (A-MYTÖ); okul müdürlerinin yönetim tarzlarını belirlemek amacıyla Üstüner (2016) tarafından geliştirilen 25 madde ve dört boyuttan oluşan beşli Likert tipi bir ölçektir. Ölçek işbirlikli, otoriter, ilgisiz ve karşı koyucu yönetim tarzı olmak üzere dört alt ölçekten oluşmaktadır. Ölçeğin, KMO değeri $=.95$ ve Bartlett Küresellik testi = $3922.76(\mathrm{df}=300, \mathrm{p}=.000)$ olarak hesaplanmış olup toplam varyansın \%67'sini açıklamaktadır. Hesaplanan Cronbach Alpha iç tutarlık katsayıları, "İşbirlikli yönetim tarzı" alt ölçeği için .92, "Otoriter yönetim tarzı" alt ölçeği için .89, "İlgisiz yönetim tarz1" alt ölçeği için .86 ve "Karş1 koyucu yönetim tarzı" alt ölçeği için .85 şeklindedir. Mevcut çalışmada ise iç tutarlılık katsayısı işbirlikli yönetim tarzı için .96 , otoriter yönetim tarzı için .87 , ilgisiz yönetim tarzı için .88 ve karşı koyucu yönetim tarzı için ise .92 olarak hesaplanmıştır.

Her iki ölçeğin seçenekleri de her zaman'dan (5) hiçbir zaman'a (1) doğru suralanmakta olup 5'li Likert tipindedir. Ölçeklerin aralık değerleri n-1/n formülüyle hesaplanmış olup (4/5= 
.80) $4.21-5.00=$ her zaman, 3.41-4.20 = çoğu zaman, 2.61-3.40 = bazen, 1.81-2.60 = nadiren, $1.00-1.80=$ hiçbir zaman şeklinde yorumlanmaktadır.

\section{İşlem}

Araştırma verileri kayıp ve uç değerler yönünden incelenmiş, basıklık ve çarpıklık değerleri kontrol edilmiştir. $\mathrm{Bu}$ değerlerinin +1 ile -1 arasında değişmesi verilerin normal dağ 11 m gösterdiği şeklinde yorumlanabilir (Büyüköztürk, 2012; Çokluk, Şekercioğlu ve Büyüköztürk, 2016). Mevcut araştırma verileri bu şartın sağlandığını göstermiştir. Ayrıca değişkenlere ilişkin ortalama değerler belirlenmiş, akabinde değişkenler arasındaki ilişkileri gösteren korelasyon değerleri incelenmiştir. Büyüköztürk (2012), korelasyon katsayısının .70-1.00 arasında olması yüksek; .30-.70 arasında olması orta; .00-.30 arasında olması ise düşük düzeyde ilişkiyi gösterdiğini ifade etmektedir. Son olarak bürokratik okul yapısı boyutları olan kolaylaştırıcı ve engelleyici bürokratik okul yapısının algılanan müdür yönetim tarzları üzerindeki yordayıcı etkisi hiyerarşik regresyon analizi ile belirlenmiştir.

\section{Bulgular}

Bu bölümde araştırma kapsamında elde edilen bulgular sırasıyla sunulmuştur. Değişkenlere ait ortalama, standart sapma ve korelasyon değerleri Tablo 1'de gösterilmektedir.

Tablo 1. Değişkenlere ait Ortalama, Standart Sapma ve Korelasyon Değerleri

\begin{tabular}{lccccccccc}
\hline $\begin{array}{l}\text { Ölçek ve } \\
\text { Boyutlar }\end{array}$ & $n$ & $\bar{X}$ & SS & KB & EB & IBYT & OYT & IYT & KKYT \\
\hline KB & 286 & 3.42 & .87 & 1 & & & & & \\
EB & 286 & 2.49 & .99 & $-.70^{* *}$ & 1 & & & & \\
IBYT & 286 & 3.62 & 1.05 & $.71^{* *}$ & $-.65^{* *}$ & 1 & & & \\
OYT & 286 & 2.88 & .99 & $-.40^{* *}$ & $.50^{* *}$ & $-.55^{* *}$ & 1 & & \\
IYT & 286 & 2.06 & .91 & $-.37^{* *}$ & $.47^{* *}$ & $-.50^{* *}$ & $.66^{* *}$ & 1 & \\
KKYT & 286 & 2.29 & 1.09 & $-.43^{* *}$ & $.52^{* *}$ & $-.64^{* *}$ & $.66^{* *}$ & $.75^{* *}$ & 1 \\
\hline $\mathrm{p}^{* *<.01}$ & & & & & & & & &
\end{tabular}

KB: Kolaylaştırıcı bürokrasi; EB: Engelleyici bürokrasi; IBYT: İşbirlikli yönetim tarzi; OYT: Otoriter yönetim tarzı; IYYT: İlgisiz yönetim tarzı; KKYT: Karşı koyucu yönetim tarzı

Tablo 1'de; kolaylaştırıcı bürokratik yapı ortalamasının $(\bar{X}=3.42)$ "çoğu zaman" ( $\bar{X}=$ 3.41-4.20); engelleyici bürokratik yapı ortalamasının ise $(\bar{X}=2.49)$ "bazen" ( $\bar{X}=2.61-3.40)$ düzeyinde olduğu görülmektedir. İşbirlikli yönetim tarzı ortalaması $(\bar{X}=3.62)$ "çoğu zaman" $(\bar{X}=3.41-4.20)$; otoriter yönetim tarzı ortalaması $(\bar{X}=2.88)$ "bazen" $(\bar{X}=2.61-3.40)$; ilgisiz yönetim tarzı ortalaması $(\bar{X}=2.06)$ ve karşı koyucu yönetim tarzı ortalaması ise $(\bar{X}=2.29)$ "nadiren" $(\bar{X}=1.81-2.60)$ düzeyindedir.

Değişkenler arasındaki korelasyon değerleri kontrol edildiğinde; kolaylaştırıcı bürokratik yapı ile işbirlikli yönetim tarzı arasında $(\mathrm{r}=.71 ; \mathrm{p}<.01)$ yüksek düzeyde ve pozitif; otoriter yönetim tarzı $(r=-.40 ; p<.01)$, ilgisiz yönetim tarzı $(r=-.37 ; p<.01)$ ve karşı koyucu yönetim $\operatorname{tarz1}(\mathrm{r}=-.43 ; \mathrm{p}<.01)$ arasında ise orta düzeyde ve negatif anlamlı ilişki bulunmaktadır. 
Engelleyici bürokratik yapı ile işbirlikli yönetim tarzı arasında $(r=-.65 ; \mathrm{p}<.01)$ orta düzeyde ve negatif; otoriter yönetim tarzı $(\mathrm{r}=.50 ; \mathrm{p}<.01)$; ilgisiz yönetim tarzı $(\mathrm{r}=.47 ; \mathrm{p}<.01)$ ve karşı koyucu yönetim tarzı $(\mathrm{r}=.52 ; \mathrm{p}<.01)$ arasında ise orta düzeyde ve pozitif anlamlı ilişki bulunmaktadır. Kolaylaştırıcı ve engelleyici bürokratik yapının işbirlikli, otoriter, ilgisiz ve karşı koyucu yönetim tarzına ait hiyerarşik regresyon sonuçları Tablo 2'de gösterilmektedir.

Tablo 2. Bürokratik Yapı ile Müdür Yönetim Tarzı Arasındaki Yordamsal İlişkilere Ait Regresyon Analizi Sonuçları

\begin{tabular}{|c|c|c|c|c|c|c|c|c|}
\hline $\begin{array}{l}\text { Bağımlı } \\
\text { Değişken }\end{array}$ & $\begin{array}{l}\text { Bağımsız } \\
\text { Değişken }\end{array}$ & $\mathrm{R}^{2}$ & $\Delta \mathrm{R}^{2}$ & B & Standart Hata & $\beta$ & $\mathrm{t}$ & $\mathrm{p}$ \\
\hline \multirow{5}{*}{$\stackrel{5}{2}$} & Sabit & \multirow[b]{2}{*}{.50} & \multirow[b]{2}{*}{.50} & .69 & .11 & \multirow[b]{2}{*}{.71} & 3.88 & .00 \\
\hline & $\mathrm{KB}$ & & & .86 & .03 & & 16.98 & .00 \\
\hline & Sabit & \multirow{3}{*}{.55} & \multirow{3}{*}{.05} & 2.40 & .35 & & 6.78 & .00 \\
\hline & $\mathrm{KB}$ & & & .60 & .08 & .50 & 8.94 & .00 \\
\hline & EB & & & -.32 & .06 & -.31 & -5.50 & .00 \\
\hline \multirow{3}{*}{5} & Sabit & \multirow[b]{2}{*}{.25} & \multirow[b]{2}{*}{.25} & 1.64 & 1.38 & & 11.89 & .00 \\
\hline & EB & & & .50 & .05 & .50 & 9.78 & .00 \\
\hline & KB & - & - & -.09 & - & - & -1.23 & .51 \\
\hline \multirow{3}{*}{ 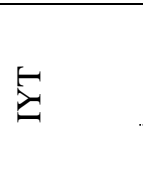 } & Sabit & \multirow[b]{2}{*}{.23} & \multirow[b]{2}{*}{.22} & .98 & .13 & & 7.63 & .00 \\
\hline & EB & & & .44 & .05 & .47 & 9.07 & .00 \\
\hline & $\mathrm{KB}$ & - & - & -.07 & - & - & -.94 & .51 \\
\hline \multirow{3}{*}{$\frac{5}{v}$} & Sabit & \multirow[b]{2}{*}{.34} & \multirow[b]{2}{*}{.34} & .70 & .14 & & 4.92 & .00 \\
\hline & EB & & & .64 & .05 & .58 & 12.03 & .00 \\
\hline & $\mathrm{KB}$ & - & - & -.05 & - & - & -.74 & .51 \\
\hline
\end{tabular}

KB: Kolaylaştıııcı bürokrasi; EB: Engelleyici bürokrasi; IBYT: İşbirlikli yönetim tarzı; OYT: Otoriter yönetim tarzı; IYY: İlgisiz yönetim tarz1; KKYT: Karşı koyucu yönetim tarzı

Tablo 2'de; bürokratik okul yapısının işbirlikli yönetim tarzını yordamasına ilişkin katkısı önem sırasına göre kontrol edildiğinde kolaylaştırıcı bürokratik yapının işbirlikli yönetim tarzını önemli ölçüde yordadığg görülmektedir $\left(\mathrm{R}^{2}=.50 ; \mathrm{t}=16.98 ; \mathrm{p}<.01\right)$. Engelleyici bürokratik yap1 boyutunun modele dâhil edilmesiyle bu yordayıcı etki daha da yükselmektedir $\left(\mathrm{R}^{2}=.55 ; \Delta \mathrm{R}^{2}=\right.$ $.05 ; \mathrm{p}<.01)$. Bu bulgu, işbirlikli yönetim tarzının yaklaşık olarak \%55'nin okulun sahip olduğu bürokratik yapıdan kaynaklandığını göstermektedir.

Engelleyici bürokratik yap1, otoriter $\left(\mathrm{R}^{2}=.25 ; \mathrm{t}=9.78 ; \mathrm{p}<.01\right)$, ilgisiz $\left(\mathrm{R}^{2}=.23 ; \mathrm{t}=9.07\right.$; $\mathrm{p}<.01)$ ve karşı koyucu $\left(\mathrm{R}^{2}=.34 ; \mathrm{t}=12.03 ; \mathrm{p}<.01\right)$ yönetim tarzlarının pozitif yordayıcısı iken; kolaylaştırıcı bürokratik yapı, otoriter $(\mathrm{t}=-1.23 ; \mathrm{p}>.05)$, ilgisiz $(\mathrm{t}=-.94 ; \mathrm{p}>.05)$ ve karşı koyucu $(\mathrm{t}=-.74 ; \mathrm{p}>.05)$ yönetim tarzlarının anlamlı yordayıcısı değildir. Otoriter yönetim tarzının $\% 25$ 'i, ilgisiz yönetim tarzının \%23'ü ve karşı koyucu yönetim tarzının \%34'ü engelleyici bürokratik yapıdan kaynaklanmaktadır. Ancak kolaylaştıııcı bürokratik yapı her üç yönetim tarzı üzerinde de yordayıcı değildir. 


\section{Tartışma, Sonuç ve Öneriler}

Öğretmen algılarına göre okullar çoğu zaman kolaylaştırıcı, bazen ise engelleyici bürokratik özellikler göstermektedir. Öğretmenlerin okullarının bürokratik yapısını orta düzeyde algıladıkları (Buluç, 2009; Demirtaş, Özdemir ve Küçük, 2016), engelleyici algıladıkları (Cerit, 2012), kolaylaştırıcı algıladıkları (Alev, 2019; Tylus, 2009; Watts, 2009), çoğunlukla kolaylaştırıcı, nadiren engelleyici algıladıkları (Erdoğan, 2012; Özer, 2010) şeklinde araştırma sonuçlarına rastlanmaktadır. Araştırma sonuçlarındaki bu farklılık bürokratik yapının yöneticilerin sergilediği yönetim stratejileri ile yakından ilgili olmasından (Yılmaz ve Beycioğlu, 2017) kaynaklanabilir. Kural ve düzenlemelerin nasıl olduğunun yanı sira yönetici tarafından nasıl eyleme döküldüklerinin önemi düşünüldügünde her yöneticinin elinde okul yapısının farklı algılara neden olduğu söylenebilir.

Okul müdürleri çoğu zaman işbirlikli, bazen otoriter, nadiren de ilgisiz ve karşı koyucu yönetim tarzı sergilemektedir. Teyfur (2011) yöneticilerin sırası ile yetkeci, koruyucu ve destekçi tarzı sergiledikleri, Sezgin-Nartgün ve Ertürk (2018) okul müdürlerinin işbirlikli yönetim tarzını yüksek, ancak otoriter, ilgisiz ve karşı koyucu yönetim tarzlarını düşük düzeyde sergiledikleri sonucuna ulaşmıştır. Argon ve Dilekçi (2014) yönetim tarzlarına ilişkin öğretmen algılarının katılıyorum düzeyinde olduğunu, Kanten ve Ülker (2014) ise yöneticilerin demokratik ve otokratik yönetim tarzlarını orta düzeyde sergilediklerini bulmuştur. Nadeem (2012) özel okul yöneticilerinin devlet okullarına göre katılımcı yönetim tarzı sergilediklerini, Netshitangani (2016) de okul yöneticilerinin genel olarak otoriter yönetim tarzı sergilediklerini tespit etmiş̧ir. Alanoğlu (2019) okul müdürlerinin işbirlikli yönetim tarzını yüksek, otoriter ve karşı koyucu yönetim tarzını orta, ilgisiz yönetim tarzını ise düşük düzeyde sergiledikleri sonucuna ulaşmıştır. Okul müdürlerinin sergiledikleri yönetim tarzı, müdürün kişisel özelliklerinden kaynaklanabileceği gibi farklı örgütsel değişkenlerden de kaynaklanabilir. Ancak genel anlamda öğretmenlerin görev yaptıkları okul müdürlerinin yönetim tarzları hakkındaki düşüncelerinin olumlu olduğu sonucu görülmektedir.

Kolaylaştırıcı yapı ile işbirlikli yönetim tarzı arasında yüksek düzeyde ve pozitif; otoriter, ilgisiz ve karşı koyucu yönetim tarzı arasında ise orta düzeyde ve negatif ilişki bulunmuştur. Engelleyici yapı ile işbirlikli yönetim tarzı arasında orta düzeyde ve negatif; otoriter, ilgisiz ve karşı koyucu yönetim tarzı arasında ise orta düzeyde ve pozitif anlamlı ilişki bulunmaktadır. Kolaylaştırıcı bürokratik yapı işbirlikli yönetim tarzını yüksek düzeyde olumlu, engelleyici bürokratik yapı ise düşük düzeyde ve olumsuz etkilemektedir. Her iki bürokratik yapı birlikte işbirlikli yönetim tarzını anlamlı şekilde etkilemektedir. Kolaylaştıııcı bürokratik yapı otoriter, ilgisiz ve karşı koyucu yönetim tarzını etkilemezken, engelleyici bürokratik yapı ise her üç yönetim tarzını pozitif etkilemektedir. Alanyazında bürokratik okul yapısının algılanan müdür yönetim tarzları üzerindeki etkisini araştıran herhangi bir çalışmaya rastlanmamıştır. Ancak bürokratik okul yapısının etkileşimci liderlik stilini etkilemediğini, ancak dönüşümsel liderliği anlamlı şekilde etkilediğini (Buluç, 2009), öğretmen tutumları üzerinde etkili olduğunu (Ömeroğlu, 2006), örgütsel vatandaşlık davranışı gösterme eğilimlerini etkilediğini (Alev, 2019; Messick, 2012), öğretmenlerin akademik iyimserlik düzeylerini anlamlı şekilde yordadığını (Messick, 2012; Özdemir ve Kılınç, 2014), profesyonel öğrenmeyi geliştirdiğini (Gray, Kruse ve Tarter, 2016) gösteren çalışma sonuçları bulunmaktadır. Bütün bu sonuçlar göz önüne alındığında okulun bürokratik yapısının öğretmen algıları üzerinde etkili olduğu ve müdürün 
sergilediği yönetim tarzının ön plana çıkmasında rol oynadığı söylenebilir. Bundan dolayı okulun sahip olduğu bürokratik yapının öğretmenlerin okul müdürlerinin sergiledikleri yönetim tarzlarına yönelik algılarını etkilemesi araştırmada öngörülen bir sonuç olarak karşımıza çıkmaktadır.

$\mathrm{Bu}$ araştırmada elde edilen sonuçlara göre öğretmenler bürokrasiye ait temel özellikler olarak ön plana çıkan iş bölümü, standartlaşma, kural ve düzenlemeleri okullarda algılamaktadır. $\mathrm{Bu}$ özellikler öğretmenler tarafından çoğunlukla görevlerini yapmalarına yardımcı olan kolaylaştırıcı unsurlar olarak görülmektedir. Ancak bazen öğretmenlerin bu özelliklerin görevlerini zorlaştırdıklarını düşündükleri söylenebilir. Öğretmenler okulun işleyişini kolaylaştırıcı algıladıklarında müdürlerinin sergilediği yönetim tarzını da işbirlikli ve demokratik algılamaktadırlar. Ancak işleyişi engelleyici algıladıklarında müdürlerinin otoriter, ilgisiz ve karşı koyucu özellikler sergilediklerini düşünmektedirler. Okullarda esnek bir yapının oluşturulması, örgütsel yapının öğretmenler tarafından sorun çözücü ve yol gösterici bir şekilde algılanmasına neden olacaktır. Bu anlamda müdür-öğretmen işbirliğinin yüksek düzeyde olması ile hem müdürün gösterdiği yönetim tarzı daha çok işbirlikli, katılımcı ve demokratik olacak hem de okulun yapısı daha çok kolaylaştırıcı algılanacaktır.

Okuldaki bürokratik yapının okulun sahip olduğu kural ve düzenlemelerin yansıması olduğu bilinmektedir. Mevcut çalışmada okulların sahip olduğu bürokratik yapı "bazen" düzeyinde engelleyici bulunmuştur. Öğretmenlerin okuldaki hangi işlem, kural ve düzenlemeleri engelleyici bulduklarına ilişkin nitel çalışmalar yapılabilir. Kolaylaştırıcı bürokratik yapının işbirlikli yönetim tarzını olumlu engelleyici bürokratik yapının ise olumsuz etkilediği tespit edilmiş olup okullarda işbirlikli yönetim tarzının etkisini artırmak için müdürler tarafından kural ve düzenlemeler, işleri kolaylaştıracak şekilde işleme koyulmalıdır. Okulların engelleyici bürokrasiye sahip olmasıyla müdürlerin olumsuz yönetim tarzlarının daha fazla algılandığı göz önüne alınarak okulun işleyişini zorlaştıran kural ve düzenlemeler müdürler tarafından sürekli bir şekilde gözden geçirilmelidir. 


\section{Kaynakça}

Adler, P. S., \& Borys, B. (1996). Two types of bureaucracy: enabling and coercive. Administrative Quarterly, 41, 61-89.

Akçakaya, M. (2016). Weber'in bürokrasi kuramının bugünü ve geleceği. Gazi Üniversitesi Sosyal Bilimler Dergisi, özel sayl, 275-295.

Alanoğlu, M. (2019). Algllanan okul müdürü yönetim tarzlart ile ögretmenlerin karara katılma, örgütsel adalet, iş doyumu ve tükenmişlik algıları arasındaki ilişskinin analizi. Yayınlanmamış doktora tezi, Frrat Üniversitesi, Elazı ̆.

Alev, S. (2019). Kolaylaştırıcı okul yapısı ve örgütsel vatandaşlık davranışları arasındaki ilişsinin incelenmesi. Uluslararası Toplum Araştırmaları Dergisi, 10(17), 420-443.

Argon, T., \& Dilekçi, Ü. (2014). Öğretmenlerin okul müdürlerinin yönetim tarzları ve kurumsal itibara yönelik algıları arasındaki ilişki. International Periodical For the Languages, Literature and History of Turkish or Turkic, 9(2), 161-181.

Aydoğan, İ. (2013). Örgüt ve yönetim kuramları. Niyazi Can (Editör), Kuram ve uygulamada eğitim yönetimi (pp. 1-32). Ankara: Pegem Akademi.

Başaran, İ. E. (2008). Örgütsel davranış insanın üretim gücü (1. baskı). Ankara: Ekinoks Yayınları.

Blake, R. R., \& Mouton, J. S. (1964). The managerial grid. Houston: Gulf Publishing.

Buluç, B. (2009). İlköğretim okullarında bürokratik okul yapısı ile okul müdürlerinin liderlik stilleri arasındaki ilişki. Ë̆itim ve Bilim, 34(152), 71-86.

Bursalığlu, Z. (2012). Eğitim yönetiminde teori ve uygulama (11. baskı). Ankara: Pegem Akademi.

Büyüköztürk, Ş. (2012). Sosyal bilimler için veri analizi el kitabl (16. baskı). Ankara: Pegem Akademi.

Cerit, Y. (2013). Okulun bürokratik yapısı ile sınıf öğretmenlerinin profesyonel davranışları arasındaki ilişki. Kuram ve Uygulamada Ĕ̈itim Yönetimi, 18(4), 497-521.

Creswell, J. W. (2017). Eğitim araştırmaları: nicel ve nitel araştırmanın planlanması, yürütülmesi ve değerlendirilmesi. (Çev. Ed. Halil Ekşi). İstanbul: EDAM Yayıncılık.

Çevikbaş, R. (2014). Bürokrasi kuramı ve yönetsel işlevi. Ekonomi ve Yönetim Araştırmaları Dergisi, $3(2), 75-102$.

Çokluk, Ö., Şekercioğlu, G., \& Büyüköztürk, Ş. (2016). Sosyal bilimler için çok değişkenli istatistik spss ve lisrel uygulamaları (4. baskı). Ankara: Pegem Akademi.

Demirtaş, Z., Özdemir, T. Y., \& Küçük, Ö. (2016). Okulların bürokratik yapısı, örgütsel sessizlik ve örgütsel sinizm arasındaki ilişki. Kuram ve Uygulamada Ĕ̆itim Yönetimi, 22(2), 193-216.

Erdoğan, U. (2012). İlköğretim okullarının bürokratik yapıları ile öğretmenlerin örgütsel sosyalleşme düzeyleri arasındaki ilişki (Malatya ili örneği). Yayınlanmamış yüksek lisans tezi, İnönü Üniversitesi, Malatya.

Gray, J. A., Kruse, S. D., \& Tarter, C.J. (2016). Enabling school structures, collegial trust and academic emphasis: Antecedents of professional learning communities. Educational Management Administration \& Leadership, 44(6), 875-891.

Hoy, W. K., \& Sweetland, S. R. (2001). Designing better schools: The meaning and nature of enabling school structure. Educational Administration Quarterly, 37, 296-321.

Hoy, W. K., \& Miskel, C. G. (2010). Educational administration theory, research and practice (Çev.Edt.Turan, S.). Ankara: Nobel Yayınları.

Kanten, P., \& Ülker, F. (2014). Yönetim tarzının üretkenlik karşııtı iş davranışlarına etkisinde işe yabancılaşmanın aracılık rolü. Sosyal Bilimler Enstitüsü Dergisi, 32, $16-40$.

Karaman, K., Yücel, C., \& Dönder, H. (2008). Öğretmen görüşlerine göre, okullardaki bürokrasi ile örgütsel vatandaşlık arasındaki ilişki. Kuram ve Uygulamada Eğitim Yönetimi, 53, $49-74$. 
Karasar, N. (2010). Bilimsel araştırma yöntemi. Ankara: Nobel Yayınları.

Kim, P. E., \& Kim, S. (2005). Profiles of schools administrators in South Korea: a comparative perspective. Educational Management Administration \& Leadership, 33(3), 286-310.

Likert, R. (1961). New patterns of management. New York: McGraw-Hill.

Messick, P. P. (2012). Examining relationships among enabling school structures, academic optimism and organizational citizenship behaviors. Unpublished doctoral dissertation, Auburn University, Auburn, Alabama, USA.

Nadeem, M. (2012). Participative management style: a tool to enhance quality education. Journal of Humanities and Social Science, 4(2), 08-14.

Namıq, F. A. (2018). Most effective management style for modern workplace. International Journal of Engineering and Management Sciences, 3(3), 402-411.

Netshitangani, T. (2016). Management style and school violence: South African perspectives. International Journal of Educational Management, 32(1), 96-106.

Ogunola, A. A., Kalejaiye, P. O., \& Abrifor, C. A. (2013). Management style as a correlate of job performance of employees of selected Nigerian brewing industries. African Journal of Business Management, 7(36), 1-8.

Ömeroğlu, Ö. (2006). Okul yönetiminde bürokrasi ile ögretmenlerin okula ilişkin tutumları arasındaki ilişki. Yayınlanmamış yüksek lisans tezi, Dokuz Eylül Üniversitesi, İzmir.

Özer, N. (2010). İlkögrretim okullarının örgütsel diriklik, bürokratiklik ve örgüt normları açısından analizi. Yayımlanmamış doktora tezi, İnönü Üniversitesi, Malatya.

Özgür, B. (2011). Yönetim tarzları ve etkileri. Maliye Dergisi, 161, 215-230.

Robbins, S. P. (2003). Organizational behaviour. New Jersey: Prentice Hall.

Sezgin Nartgün, Ş., \& Ertürk, R. (2018). Okul müdürlerinin okul yönetim tarzları ile örgüt iklimi arasındaki ilişki. A. İşcan (Editör). Eğitim bilimlerinde örnek araştırmalar (ss. 221-243). Ankara: Nobel Yayınları.

Simkins, T. (2005). Leadership in Education: What works or what makes sense? Educational Management Administration \& Leadership, 33(1), 9-26.

Teyfur, M. (2011). Illköğretim okul yöneticilerinin uyguladıkları yönetim biçimlerine ilişkin alglları ve velilere göre okul yöneticilerinin yönetim becerilerinin değerlendirilmesi. Yayınlanmamış doktora tezi, Atatürk Üniversitesi, Erzurum.

Türk Dil Kurumu. (2019). Türk dil kurumu büyük sözlüğü. [Çevrim-içi: http://www.tdk.gov.tr/index.php?option=com_bts], Erişim tarihi: 28.04.2019.

Tylus, J. (2009). The impact of enabling school structures on the degree of internal school change as measured by the implementation of professional learning communities. Unpublished doctoral dissertation, Virginia Commonwealth University, Richmond, Virginia, USA.

Üstüner, M. (2016). Algılanan müdür yönetim tarzı ölçeğinin geçerlik ve güvenirlik çalışması. Kuram ve Uygulamada Ĕ̌itim Yönetimi, 22(3), 429-457.

Watts, D. M. (2009). Enabling school structure, mindfulness, and teacher empowerment: test of a theory. Unpublished doctoral dissertation, Department of Educational Leadership, The University of Alabama, Alabama, USA.

Yayla, Y. (2001). Kanuni Sultan Süleyman devri Osmanlı Devleti'nde bürokratik yapı (1520-1566). Yayınlanmamış yüksek lisans tezi, Süleyman Demirel Üniversitesi, Isparta.

Yılmaz, M. (2016). Okul yöneticilerinin yönetim tarzlarının sosyo-demografik faktörleri bağlamında incelenmesi: kadın yöneticiler üzerinde bir araştırma. 21. Yüzyllda Eğitim ve Toplum, 5(15), 293-313. 
Yılmaz, A. İ., \& Beycioğlu, K. (2017). Okullardaki bürokratik yapıya ilişkin öğretmen görüşleri. Anadolu Üniversitesi Eğitim Fakültesi Dergisi, 1(2), 1-23. 


\section{Extended Abstract}

\section{Introduction}

Coordinating more than one person and ordering the work they do require the existence of certain rules and regulations. Therefore, the existence of bureaucracy cannot be denied in the functioning of all the structures organized in order to eliminate a social need. The rules and regulations that are put into work are sometimes seen by the employees as enabling and sometimes they can be perceived as obstructive. Schools, like all other organizations, work within the framework of certain rules while performing the applications expected from them. It is common for teachers to perceive these rules and the way these rules are put on the job differently. At the same time, the rules and regulations of the school will determine the functioning of the school and will shape the principal's behavior. Therefore, the principal's management style may be affected by the bureaucratic structure of the school. In addition, the principal is expected to influence the bureaucratic structure of the school in the form of recruiting rules and regulations. In other words, while the bureaucratic structure with the same characteristics is perceived as enabling with some principal, it can be perceived as obstructive with other principal.

When the studies in the literature were examined, it was seen that the bureaucratic structure of the school affected many organizational and individual variables. One of the variables influenced by the bureaucratic structure of the school is thought to be the perceived principal management style. Therefore, it is worth noting that the relations between these variables are examined. However, no studies have examined the relationships between these two variables. The purpose of this study was to determine the relationships between bureaucratic school structure and principal management style.

\section{Method}

In this study, which aims to determine the relationships between bureaucratic school structure and principal management style according to teacher opinions, relational survey model was used. A total of 286 teachers were reached by a simple random sampling method among the teachers working in 65 state high schools in the city center of Mersin. The gathering research data "Enabling School Structure" and "Perceived Principal Management Style" scales were used. The collected data were examined for loss and extreme values and the skewness and kurtosis values were checked. Then, descriptive values of variables were determined and correlation and regression analysis were performed.

\section{Results}

According to teachers' perceptions, schools often exhibited enabling and sometimes exhibited obstructive bureaucratic structure characteristics. Principals often exhibited cooperative management style; sometimes exhibited authoritative management style; rarely exhibited indifferent and resistant management styles.

The relationship between enabling bureaucratic structure and the cooperative management style was high and positive; between enabling bureaucratic structure and authoritative, indifferent and resistant management style was moderate and negative. The relationship between obstructive bureaucratic structure and cooperative management style was 
moderate and negative; between obstructive bureaucratic structure and authoritative, indifferent and resistant management style was moderate and positive.

The results of the hierarchical regression showed that the bureaucratic school structure, which enabling and obstructive, had a significant effect on the cooperative management style. The obstructive bureaucratic structure positively affected the authoritative, indifferent and resistant management styles, and the enabling structure did not affect all three management styles.

\section{Discussion and Conclusion}

Teachers often perceived the bureaucracy in their schools as enabling and sometimes as obstructive. Research results in the literature showed that there are different opinions about the bureaucratic structures of schools. The bureaucratic structure is closely related to the management strategies of managers. It can be said that how rules and regulations are actually acted by the manager as well as how they affect the perception of bureaucratic structure.

Principals exhibit a high level of cooperative, moderately authoritative, and low-level, indifferent and resistant management style. The management style of their managers may be caused by their personal characteristics and may also arise from different organizational variables. It was evaluated that examining the variables affecting the management styles of the principals would be appropriate. When the results of the study are taken into consideration, it can be said that the bureaucratic structure of the school has an effect on the perceptions of the teachers about the management styles of the principals and has a role in the emergence of the management style.

The results obtained in the present study can be said to be the main features of bureaucracy, the division of labor, standardization, rules and regulations are seen as enabling elements that help teachers to perform their duties, and sometimes they think that these features make their tasks difficult. Teachers who perceive the functioning of the school are enabling also perceived their managers as cooperative and democratic. However, when they perceive functioning as obstructive, they perceive the style of management as authoritative, indifferent and resistant. The organizational structure in schools should be problem-solving and guiding in a flexible way, and principal-teacher cooperation should be kept at a high level. Thus, the management style shown by the principal will be perceived as collaborative, participative and democratic, and the structure of the school will be perceived more enabling. 